\title{
PELATIHAN MODEL PEMBIAYAAN UNTUK INDUSTRI KREATIF DI KOTA BANDUNG
}

\author{
Rivani $^{*}$, Muhammad Rizal' ${ }^{2}$, dan Rudi Saprudin Darwis ${ }^{3}$. \\ ${ }^{1}$ Departemen Ilmu Administrasi Bisnis, FISIP, Universitas Padjadjaran \\ ${ }^{2}$ Departemen Ilmu Administrasi Bisnis, FISIP, Universitas Padjadjaran \\ ${ }^{3}$ Departemen Kesejahteraan Sosial, FISIP, Universitas Padjadjaran \\ Email: rivani@unpad.ac.id
}

\begin{abstract}
ABSTRAK. Program pelatihan ini bertujuan untuk mencari permasalahan utama khususnya bidang pembiayaan untuk sektor industri kreatif, untuk mencari alternatif model pembiayaannya, dan terakhir untuk mencoba merancang model pembiayaan untuk sektor industri kreatif. Metode pelatihan yang digunakan adalah metode andragogi dengan media dan alat bantu yang disesuaikan kebutuhan. Selain itu sebelumnya dilakukan wawancara terlebih dahulu untuk mencari informasi yang dapat mendukung rencana pelatihan yang lebih sesuai dengan kebutuhan para peserta. Berdasarkan hasil wawancara didapat informasi memang umumnya para peserta belum memanfaatkan internet untuk keperluan pembiayaan usahanya. Sedangkan dari evaluasi pelatihan dapat disimpulkan bahwa pelatihan terlaksana dengan baik, peserta cukup antusias, hanya saja mereka berpendapat bahwa waktu pelatihan kurang banyak untuk memberi kesempatan lebih pada mereka dalam mempraktekkan model pembiayaan melalui internet hingga benar-benar paham.
\end{abstract}

Kata kunci: Pembiayaan Usaha; Industri Kreatif. (Business Financing; Creative Industry)

ABSTRACT. This training program aims to find the main problems, especially in the field of financing for the creative industry sector, to find alternative financing models, and finally to try to design a financing model for the creative industry sector. The training method used is the andragogy method with media and tools that are tailored to it needs. In addition, interviews were conducted in advance to seek information that could support training plans that were more appropriate to the needs of the participants. Based on the results of the interviews, information was obtained that the participants generally did not use the internet for financing their business needs. Whereas from the training evaluation it can be concluded that the training was carried out well, the participants were quite enthusiastic, only they thought that the training time was not enough to give them more opportunities in practicing financing models through the internet to have better understanding about it.

\section{PENDAHULUAN}

Saat ini industri kreatif di berbagai negara maju dan berkembang sedang tumbuh. Di Indonesia sendiri, Hasil survey BPS di tahun 2015 menunjukkan industri kreatif tumbuh 4,38 persen. Kontribusi industri kreatif terhadap perekonomian Indonesia mencapai 7,38 persen dari total perekonomian nasional. Jika dirupiahkan, nilainya mencapai $\mathrm{Rp} 852,24$ triliun. Industri ini mampu memberikan lapangan kerja bagi sedikitnya 15,9 juta orang serta berkontribusi terhadap nilai ekspor sebesar US\$ 19,4 Miliar.
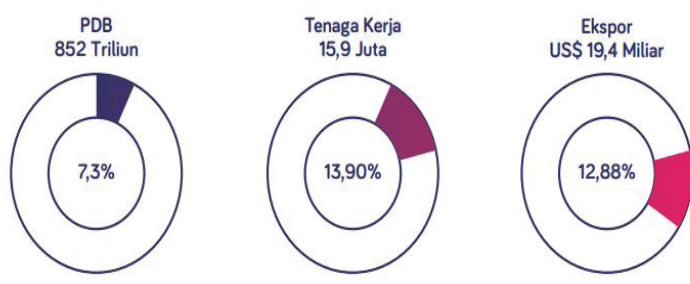

(Bekraf, 2017)

Gambar 1. Kondisi Pertumbuhan Ekonomi Kreatif di Indonesia

Berdasarkan riset (Bekraf, 2017) ada beragam masalah yang dapat menghambat pertumbuhan ekonomi kreatif, yakni: kualitas-kuantitas SDM, aspek teknologi, akses pasar, kolaborasi stakeholder, dan yang cukup dominan adalah akses permodalan yang minim. Minimnya akses modal dikarenakan karakteristik industri kreatif yang unik dan beresiko ini menyebabkan mayoritas pelaku harus memodali usahanya sendiri, sedikit sekali yang mampu mengakses bank, dan kurang dari $1 \%$ dibiayai dari modal ventura. Oleh karena itu, bisnis kreatif ini membutuhkan tipe akses permodalan yang tidak biasa, dimana hal ini tidak memerlukan jaminan, tingkat kepercayaan penuh, serta dapat mentolerir tingkat resiko kegagalan usaha yang tinggi. Umumnya alternatif permodalan untuk startup bisnis kreatif ini didapat dari angel investor, ataupun memanfaatkan dana hibah dari pemerintahan / CSR (Corporate Social Responsibility) dari perusahaan besar.
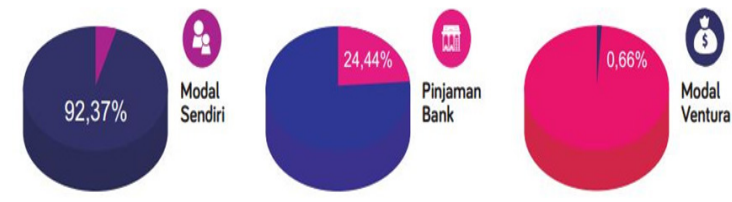

(Bekraf \& BPS, 2017)

Gambar 2. Gambaran Akses Pembiayaan Usaha pada Sektor Industri Kreatif

Oleh karena itu diperlukan pelatihan mengenai alternatif model pembiayaan bagi industri kreatif, sehingga diharapkan tersosialisasikannya suatu alternatif model pembiayaan yang dapat lebih sesuai dengan karakteristik industri kreatif yang unik ini.

\section{METODE}

Industri kreatif didefinisikan sebagai industri yang berasal dari pemanfaatan kreativitas, keterampilan serta bakat individu untuk menciptakan kesejahteraan 
serta lapangan pekerjaan dengan menghasilkan dan memberdayakan daya kreasi dan daya cipta individu tersebut (Kemendag, 2008). Lebih sederhana dapat disebutkan bahwa danya suatu inovasi dalam suatu perusahaan dapat dikategorikan industri kreatif (Green et al, 2007).

Definisi Industri Kreatif berdasarkan UK DCMS Task force 1998 (dalam Siti Nurjanah, 2013) adalah: "Creatives Industries as those industries which have their origin in individual creativity, skill \& talent, and which have a potential for wealth and job creation through the generation and exploitation of intellectual property and content"

Berdasarkan Perpres Nomor 72 Tahun 2015 tentang Perubahan Atas Peraturan Presiden Nomor 6 Tahun 2015 Tentang Badan Ekonomi Kreatif telah mengklasifikasi ulang sub-sektor industri kreatif 16 sub-sektor, yaitu: Aplikasi dan Game, Arsitektur, Desain Interior, Desain Komunikasi Visual, Desain Produk, Fashion, Film, Animasi dan Video, Fotografi, Kriya, Kuliner, Musik, Penerbitan, Periklanan, Seni Pertunjukan, Seni Rupa, Televisi dan Radio.

Menurut Riyanto (2002) jenis sumber pembiayaan itu secara garis besar ada dua: Dari internal (dari dalam perusahaan), dan dari eksternal (dari luar perusahaan). Lebih spesifik dijelaskan bahwa jenisjenis pembiayaan usaha itu adalah sebagai berikut : Dana sendiri, Patungan (join saham), Pinjaman, baik itu dari sektor formal (bank, lembaga keuangan mikro, dsb) maupun informal (pinjaman dari saudara, dsb), Hibah, baik itu dari sektor formal (program pemerintah, dsb) maupun informal (hibah dari keluarga, dsb.

Salah satu alternatif sumber pembiayaan di era sekarang ini adalah: crowdfunding, dimana proses penggalangan dana yang difasilitasi oleh platform digital. Adapun Crowdfunding dapat dibedakan menjadi 4 kategori utama, yaitu (Husain \& Root, 2015): 1. Donation-based, berbasis donasi biasanya untuk kepentingan sosial, 2. Reward-based, mirip donasi, tetapi pembuat proyek menawarkan hadiah atas donasinya, 3 . Lending-based, galang dana ini bersifat pinjaman yang menawarkan keuntung bunga atau bagi hasil, 4. Equitybased, galang dana ini menawarkan keuntungan sebagian saham perusahaannya.

Menurut Riyanto (2002) faktor-faktor yang mempengaruhi keputusan pendanaan adalah tingkat bunga, stabilitas earning, susunan aktiva, kadar risiko dari aktiva, jumlah modal yang diperlukan, keadaan pasar modal, sifat manajemen dan ukuran perusahaan. Brigham and Weston (1997) mengungkapkan bahwa faktor-faktor yang mempengaruhi keputusan pendanaan adalah stabilitas penjualan, likuiditas, struktur aktiva, operating leverage, tingkat pertumbuhan, profitabilitas, produktivitas, pajak, pengendalian, sikap manajemen, kondisi pasar keuangan dan fleksibilitas keuangan. Menurut Sartono (2001), faktor-faktor yang mempengaruhi keputusan pendanaan adalah tingkat penjualan, struktur aset, tingkat pertumbuhan perusahaan, profitabilitas, variabel laba dan pajak, skala perusahaan, kondisi internal perusahaan, dan ekonomi makro.

Adapun kerangka permasalahan dari program ini adalah kebutuhan pengembangan sektor industri kreatif membutuhkan alternatif sumber pembiayaan yang baru, selain dari sumber pembiayaan yang sudah ada. Hal ini dikarena karakteristik khusus yang dimiliki sektor industri kreatif yang kurang bersahabat dengan kebutuhan persyaratan pembiayaan usaha pada lembaga keuangan bank/non bank normal pada umumnya. Salah satu alternatif model pembiayaan yang dapat dimanfaatkan adalah model crowdfunding. Hal ini karena model crowdfunding memiliki persyaratan yang relatif lebih ringan dan juga potensi untuk mendapatkan pembiayaan yang tidak terbatas.

Berdasarkan kerangka pemecahan masalah tersebut, maka program yang diajukan adalah pelatihan model pembiayaan bagi industri kreatif di Kota Bandung. Dengan demikian di harapkan para pelaku industri kreatif dapat mengetahui dan memanfaatkan model pembiayaan untuk pengembangan bisnis industri kreatifnya.

Adapun mengenai khalayak sasaran yang dituju untuk program pelatihan ini dapat dilihat pada tabel berikut ini:

\section{Tabel 1. Khalayak Sasaran Program}

\begin{tabular}{lll}
\hline No. & \multicolumn{1}{c}{ Mitra } & \multicolumn{1}{c}{ Profil Mitra } \\
1. & $\begin{array}{l}\text { Pelaku Industri } \\
\text { Kreatif }\end{array}$ & $\begin{array}{l}\text { Perwakilan dari 16 Subsektor } \\
\text { Industri Kreatif }\end{array}$ \\
2. & $\begin{array}{l}\text { Masyarakat Calon } \\
\text { Pengusaha/UKM }\end{array}$ & $\begin{array}{l}\text { Perwakilan dari komunitas } \\
\text { 3. }\end{array}$ \\
& Masyarakat Umum & $\begin{array}{l}\text { Perwakilan dari masyarakat di } \\
\text { Kelurahan setempat }\end{array}$ \\
4. & $\begin{array}{l}\text { Pemerintah Daerah/ } \\
\text { Desa }\end{array}$ & $\begin{array}{l}\text { Dinas Perindustian dan } \\
\text { Perdagangan } \\
\text { 5. }\end{array}$ \\
\hline
\end{tabular}

Mengenai tahapan pelaksanaan program ini, dapat dilihat pada gambar berikut ini:

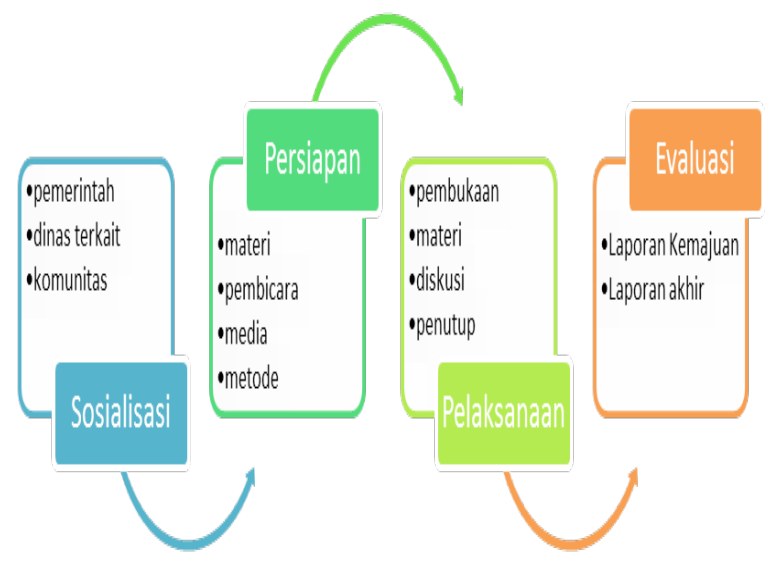

Gambar 3. Tahapan pelaksanaan Program Pelatihan 


\section{HASIL DAN PEMBAHASAN}

Berdasarkan tahapan proses kegiatan yang telah di rancang, sampai saat ini tim pelaksana sudah melaksanakan beberapa tahapan, diantaranya yaitu:

1. Pengurusan surat-surat dari pihak terkait

Pengurusan surat-surat ini di perlukan untuk sebagai legalitas pelaksanaan program, agar disaatimplementasi program, pihak pelaksana dapat dukungan dari para stakeholder.

2. Rapat pembentukan tim pelaksana pelatihan

Dalam hal ini mulai dipilih dan dibentuk tim pelaksana program pelatihan ini, mulai dari anggota lapangan yang menyiapkan bahan observasi, konsumsi, perijinan, undangan, daftar absen, lembar evaluasi, dan hal yang bersifat teknis lainnya, Selain itu disiapkan juga pemateri dan tenaga pendukung untuk agar pelaksanaan program pelatihan dapat berjalan optimal.

3. Observasi dan persiapan

Dalam hal ini dilakukan proses observasi ke lapangan atau kelompok calon peserta pelatihan dalam bentuk need assessment. Dengan demikian nantinya di dapat bahan atau materi kebutuhan pelatihan yang didapat dari calon kelompok peserta pelatihan. Dari hasil analisa awal ini, setidaknya akan berguna dalam perancangan materi, metode, media dan alat bantu yang akan digunakan nanti pada saat pelatihan dilaksanakan. Pada tahapan ini juga, sebelumnya dilaksanakan wawancara terhadap beberapa pelaku industri kreatif ini, sehingga didapat informasi yang bermanfaat untuk menambah persiapan perancangan pelatihan yang lebih sesuai dengan kebutuhan para pelaku industri kreatif. Berikut ini beberapa hasil wawancaranya :

A. Menurut Bapak/Ibu, apa saja kendala terbesar dari usahanya ? umumnya responden menjawab kendala terbesar mereka adalah pemasaran dan permodalan.

B. Menurut Bapak/Ibu, apa sajakah keunggulan dari usahanya ? umumnya responden menjawab keunikan dan harga yang terjangkau merupakan keunggulan usahanya.

C. Menurut Bapak/Ibu, dukungan apa saja yang anda harapkan dari Pemerintah ? Perusahaan Swasta ? Akademisi ? dalam pengembangan usaha anda. Umumnya responden menjawab dukungan lebih banyak pada aspek pelatihan, fasilitasi pasar dan dukungan modal dengan bunga murah.

D. Menurut Bapak/Ibu, sejauh mana industri kreatif telah memanfaatkan teknologi internet untuk pengembangan bisnis nya ? untuk aspek produksi? SDM ? pemasaran ? keuangan ? Umumnya para responden menjawab pemanfaatan teknologi internet masih terbatas pada aspek pemasaran dan sedikit pada aspek produksi ( design ).

E. Menurut Bapak/Ibu, alternatif terbaik untuk pembiayaan usaha (selain modal sendiri/ saudara/keluarga) di bidang industri kreatif ini adalah umumnya responden menjawab investor dikarenakan syarat nya tidak rumit atau atas kesepakatan bersama.

F. Pernahkan mendengar / memanfaatkan satu situs pembiayaan usaha via internet ? bila pernah, sebutkan nama situsnya, dan jelaskan mekanismenya, maupun keunggulan maupun kelemahannya. Umumnya para responden memang menjawab belum pernah. Kalaupun pernah masih berkisar pada model pembiayaan kredit berbunga via internet saja.

Demikian paparan hasil wawancara dengan beberapa pelaku industri kreatif di Kota Bandung, dimana informasi ini dapat dimanfaatkan untuk merancang program pelatihan yang lebih sesuai dengan kebutuhan para peserta.

Adapun tahapan yang telah dilakukan pada program pelatihan ini adalah sebagai berikut :

1. Persiapan Pelatihan

Pada tahap ini dilakukan sosialisasi rencana program pelatihan pada pihak-pihak terkait. Selain itu juga disiapkan untuk kembali orientasi pada anggota tim agar setiap anggota kembali memahami rencana dan tugas masing-masingnya. Selain itu pembicara menyiapkan materi, metode dan media yang dirancang berdasarkan hasil observasi lapangan tim sebelumnya. Tim pendukung juga menyiapkan dokumen dan media dokumentasi untuk pelaksanaan pelatihan ini.

2. Pelaksanaan Pelatihan

Pelatihan dibuka oleh pejabat berwenang dan ketua pelaksana dan dimulai dengan doa terlebih dahulu. Lalu pemberian materi ke peserta yang selanjutnya akan ada sesi tanya - jawab atau diskusi untuk pendalaman materi. Setelah itu ada sesi evaluasi pelatihan, sebelum kemudian acara di tutup dengan doa.

3. Evaluasi Pelatihan

Pada tahap ini dilakukan proses pengolahan data evaluasi pelatihan, sebagai bahan dasar untuk melakukan analisa pada penyusunan laporan akhir. Berdasarkan pengamatan dan wawancara dengan beberapa peserta didapat informasi bahwa para peserta cukup antusias dalam mengikuti pelatihan ini. Hanya saja saran mereka agar waktu diperpanjang sehingga ada kesempatan bagi mereka untuk mempraktikkan bagaimana memanfaatkan internet untuk kebutuhan pembiayaan usaha mereka.

4. Penyusunan laporan akhir

Tahap ini adalah proses rekapitulasi data, analisa data, pembahasan serta penyusunan laporan akhir.

\section{SIMPULAN}

Pelaksanaan program pengabdian pada masyarakat dengan tema pelatihan model pembiayaan 
industri kreatif di Kota Bandung ini sudah selasai dilaksanakan dengan baik. Respon para peserta baik, pihak pendukung juga baik, serta peran serta mahasiswa dalam mendukung pelaksanaan program ini juga baik. Adapun kendala yang dihadapi selama pelaksanaan program adalah adanya gangguan warga untuk demo ke kantor kecamatan, sempat mengganggu jalannya pelatihan, tetapi hal ini dapat ditanggulangi dengan baik oleh tim dengan cara memindahkan acara ke kantor RW terdekat. Selain itu waktu pelaksanaan program di tengah-tengah waktu perkuliahan reguler juga membuat pertemuan persiapan program dengan mahasiswa yang terlibat menjadi lebih sulit dilakukan.

Dari kesimpulan tersebut, ada beberapa saran rekomendasi yang dapat diajukan untuk perbaikan pelaksanaan program ini ke depan, yaitu :

1. Pelatihan perlu dilakukan dengan waktu yang lebih panjang, agar ada kesempatan peserta untuk mempraktekkan model pembiayaan usaha yang lebih baik.

2. Pelatihan perlu dilengkapi dengan sarana komputer yang cukup, agar peserta dapat mensimulasikan langsung model pembiayaan usahanya dengan lebih baik.

3. Perlu disiapkan plan B, untuk segala rancangan program, untuk mengantisipasi kejadian yang tidak terduga yang dapat menggannggu kelancaran pelaksanaan program ini.

4. Waktu pelaksanaan program lebih baik bila tidak dilakukan pada saat pelaksanaan perkuliahan reguler berlangsung, dengan demikian proses pertemuan persiapan program dapat dilakukan dengan lebih mudah lagi.

\section{DAFTAR PUSTAKA}

Bekraf. (2017). Outlook Ekonomi Kreatif Indonesia. Badan Ekonomi Kretif Indonesia. Jakarta.

Brigham E.F. Dan Weston J.Fred. (1997). Dasar-Dasar Menejemen Keuangan, Edisi Sembilan Jilid 1, Jakarta; Erlangga.

Green, L., I. Miles, J. Rutter (2007), Hidden Innovation In The Creative Industries,Nesta Working Paper, London

Husain, S., \& Root, A. (2015). Crowdfunding For Entrepreneurship. Alliedcrowds. London: Alliedcrowds.

Riyanto, Bambang (2002) Dasar-Dasar Pembelanjaan Perusahaan, Edisi 4. Yogyakarta: Bpfe.

Sartono, Agus. (2001). Manajemen Keuangan Teori Dan Aplikasi. Edisi 4. Yogyakarta; Bpfe-Yogyakarta

Siti Nurjanah (2013) Analisis Pengembangan Program Bisnis Industri Kreatif Penerapannya Melalui Pendidikan Tinggi, Jma Vol. 18 No. 2.

Kementerian Departemen Perdagangan RI (2008), "Pengembangan Ekonomi Kreatif Indonesia", Studi Industri Kreatif Indonesia, Departemen Perdagangan RI, Jakarta

Peraturan Presiden Republik Indonesia Nomor 72 Tahun 2015 Tentang Perubahan Atas Peraturan Presiden Nomor 6 Tahun 2015 Tentang Badan Ekonomi Kreatif 